\title{
Diagnostic hysteroscopy in the mare - uterine contamination and endometrial reaction
}

\author{
Viola Schiemann, C.P. Bartmann', Gabriele Kirpal2, Alexandra v. Reiswitz', H.-A. Schoon ${ }^{3}$ and E. Klug \\ Clinic for horses, ${ }^{2}$ Institute of Microbiology, School of Veterinary Medicine Hannover, Germany \\ ${ }^{3}$ Institute of Veterinary Pathology, University of Leipzig, Germany
}

\begin{abstract}
Summary
Despite the fact that, nowadays, hysteroscopy is performed routinely, in equine gynecology, for diagnostic and minimally invasive surgical treatment, certain aspects should be considered in order to gain optimal conditions and results for the mare and for those carrying out the examination. These include thorough ascertainment of indication, careful uterine distension, choice of the correct stage of cycle and establishment of an adequate follow-up treatment and management. In order to monitor possible changes in the health of the genital tract following diagnostic hysteroscopy the clinical, microbiological (uterine swab) and pathohistological (endometrial biopsy) state of eight diestrous mares were examined before performance of a hysteroscopy, five days later and after the estrus which followed. Uterine distension was established by insufflation of filtered air. No follow-up treatment was carried out.

At the outset all eight mares were clinically healthy, without evidence of pathogenic microbes in the uterine swabs or inflammatory alterations in the endometrial samples.

Five days after hysteroscopy pathogenic microbes were detected in $50 \%$ of the mares (in three cases: slight amount of Pseudomonas aeruginosa, in one case: moderate amount of E.coli and slight amount of $\beta$-haemolytic Streptococcus). This last mare revealed a clinically discernable endometritis. Endometrial biopsy enabled a diagnosis of moderate, acute, superficial endometritis in this mare. A further five of the eight mares developed slight acute inflammatory endometrial reaction which was only detected through pathohistology, though only two of them showed the presence of pathogenic microbes.

Following the subsequent estrus all mares were clinically healthy. In two mares Pseudomonas aeruginosa persisted, the others were not contaminated with pathogenic microbes.

Two further mares still showed slight, acute, inflammatory endometrial reactions.

A remarkable finding in the endometrial biopsies was the striking rise in the number of eosinocytes in the superficial layers of the endometrium five days after hysteroscopy, seen in six of eight mares. After the following estrus the number of eosinocytes was still obviously elevated in four mares. A contamination rate of $50 \%$ shows that a prevention of endometrial infection is indicated after hysteroscopy, for example through the infusion of mild antiseptic solutions into the uterus. Additional induction of estrus can advance uterine clearance.

Independent of intrauterine contamination, $75 \%$ of the mares showed inflammatory endometrial reactions on pathohistology. It might therefore be recommendable not to use the following estrus for insemination.

The aetiology of the endometrial eosinophilia following uterine distension through insufflation of filtered air is to date unknown. A correlation between poor vulvovestibular conformation and eosinophilic infiltration of the endometrium has been established by other authors in the past and a connection here seems likely.
\end{abstract}

Keywords: mare, hysteroscopy, contamination, endometrial reaction

\section{Die diagnostische Hysteroskopie beim Pferd - uterine Kontamination und endometriale Reaktion}

Die Hysteroskopie hat sich in der Gynäkologie des Pferdes inzwischen zu einem routinemäßig eingesetzten Verfahren in der erweiterten Diagnostik sowie in der minimal invasiven Fertilitätschirurgie entwickelt. Um für die Hysteroskopie günstige Untersuchungsbedingungen zu schaffen und einen für die Stute schonenden Eingriff zu sichern, ist eine sorgfältige Indikationsstellung sowie eine Optimierung der Rahmenbedingungen anzustreben. Diese beinhalten eine schonende Uterusdistension, die Wahl des richtigen Zyklusstadiums sowie geeignete Nachversorgung und weiterführendes Management. Im Rahmen vorliegender Studie wurden die Auswirkungen einer diagnostischen Hysteroskopie bei acht geschlechtsgesunden Stuten hinsichtlich der uterinen Kontamination, endometrialen Reaktion sowie auf die klinische Geschlechtsgesundheit überprüft. Dazu wurden acht interöstrische Stuten vor Durchführung einer Hysteroskopie, fünf Tage danach und nach dem folgenden Östrus klinisch, mikrobiologisch (Uterustupfer) und pathohistologisch (Endometriumbiopsie) untersucht. Die uterine Distension wurde mittels Insufflation gefilterter Luft hergestellt. Eine Nachbehandlung wurde nicht durchgeführt.

Bei der Voruntersuchung waren alle Stuten klinisch geschlechtsgesund, ohne nachweisbaren intrauterinen Keimgehalt und zeigten keine entzündlichen Veränderungen im Endometrium.

Fünf Tage nach der Hysteroskopie waren bei der Hälfte der Stuten pathogene Keime nachweisbar (in drei Fällen ein geringgradiger Gehalt an Pseudomonas aeruginosa, in einem Fall ein mittelgradiger Gehalt an Escherichia coli und ein geringgradiger Gehalt an $\beta$-hämolysierenden Streptokokken). Letztgenannte Stute entwickelte einen klinisch manifesten Genitalkatarrh. In der Endometriumbiopsie dieser Stute wurde eine mittelgradige akute oberflächliche eitrige Endometritis diagnostiziert. Bei weiteren fünf Stuten konnte ausschließlich pathohistologisch eine geringgradige akute endometriale Entzündungsreaktion festgestellt werden, obwohl lediglich bei zwei dieser Stuten ein pathogener Keimgehalt nachweisbar war.

Nach dem folgenden Östrus waren alle Stuten klinisch geschlechtsgesund. Bei zwei Tieren persistierte Pseudomonas aeruginosa, zwei weitere zeigten noch eine geringgradige akute endometriale Entzündungsreaktion. Die übrigen waren unauffällig.

Ein bemerkenswerter pathohistologischer Befund war ein auffälliger Anstieg der Eosinophilenzahl in der Lamina propria mucosae des Endometriums fünf Tage nach Hysteroskopie bei sechs der acht Stuten. Nach dem folgenden Östrus konnte noch bei vier Stuten eine deutlich erhöhte Eosinophilenpräsenz festgestellt werden.

Eine Kontaminationsrate von 50\% macht deutlich, dass zur Prevention intrauteriner Infektionen eine lokale antiseptische Behandlung in einer milden Jodlösung, indiziert ist. Die zusätzliche Rosseeinleitung kann den Prozess der uterinen Reinigung beschleunigen. Unabhängig von der 
intrauterinen Kontamination waren bei 75\% der Stuten pathohistologisch entzündiche Endometriumsreaktionen nachweisbar. Es scheint somit ratsam, den einer Gebärmutterspiegelung folgenden Östrus nicht für eine Belegung zu nutzen.

Die Ätiologie der endometrialen Eosinophilie nach uteriner Distension mittels gefilterter Raumluft ist bislang nicht bekannt. Ein Zusammenhang zwischen einer schlechten Schlussfunktion des Vulvovestibularkomplexes mit der möglichen Folge einer Pneumometra und einer Eosinophileninfiltration ins Endometrium wurde bereits von anderen Autoren vermutet und scheint vor diesem Hintergrund wahrscheinlich.

Schlüsselwörter: Pferd, Hysteroskopie, Kontamination, endometriale Reaktion

\section{Introduction}

Hysteroscopy has developed into a routinely employed procedure for supplementary diagnostic and minimally invasive surgical therapy in equine gynaecology. To create favourable conditions for a hysteroscopic examination and to ensure a safe operation for the mare it is necessary to consider the indication carefully and to optimise the working conditions and the method, including an appropriate follow-up treatment.

\section{Indications}

Diagnostic hysteroscopy is mainly indicated in mares which are without findings in the clinical, ultrasonographical and microbiological examination in order to explain the fertility problems. Furthermore in cases of unclear findings in the basic gynaecological examination hysteroscopy can be helpful to visualise intrauterine content, lesions, neoplasms and cysts in terms of their respective quality, localisation and amount (Figure la, $1 \mathrm{~b}$ and 2). If it is possible to make a definite diagnosis through clinical and ultrasonographical examination, for example in cases of endometritis or poor vulvovestibular conformation, suitable therapy should be the first measure; hysteroscopy is indicated in cases where the infertility remains (Kähn 1993, Bartmann et al. 2000b).

Operative hysteroscopy is primarily performed for the minimal invasive resection of endometrial cysts. Further indications are intrauterine adhesiolysis and surgical therapy of uterine tumours (Kähn 1993, Bracher et al. 1994, Bartmann et al. 2000a, b). Recently hysteroscopy is used for the directed insemination onto the orifice of the fallopian tube in order to reduce sperm-dose (Morris et al. 2000).

\section{Uterine distension}

To achieve complete visualization of endouterine structures, and with that the establishment of an effective hysteroscopic examination, a sufficient distension of the uterine cavity is required. Liquid or gaseous media are available for dilatation. As liquid media, sterile water or saline can be used. Depending on the size of the uterus one to four litres of fluid are instilled through the working channel of the endoscope or through an additional catheter by means of gravity (Wilson 1983, LeBlanc 1993). A disadvantage of these media is the inability to perform electro-surgery.

The preferential gaseous medium is filtered atmospheric air (Bracher et al. 1992, Kähn 1993, Threlfall and Carleton 1997, Bartmann et al. 1997, 2000a, b). Insufflation can be established through the endoscopic pump. A study has shown that an average intrauterine pressure of $25 \pm 5 \mathrm{mmHg}$ is adequate for complete distension of the cavum uteri, with pressures exceeding $40 \mathrm{mmHg}$ never being necessary (Schiemann 2001). Intrauterine pressures higher than these values can induce spontaneous reactions of irritation in the mare as well as placing a strain on the mare's circulatory system and are therefore unwelcome (Schiemann 2001). Because of the higher risk of superelevating intrauterine pressures when using high rates of gas flow for insufflation, application using pumps with flow rates limited to a maximum of $4 \mathrm{l} / \mathrm{min}$ are recommended, in particular if there is no possibility of monitoring the pressure (Schiemann et al. 2000).
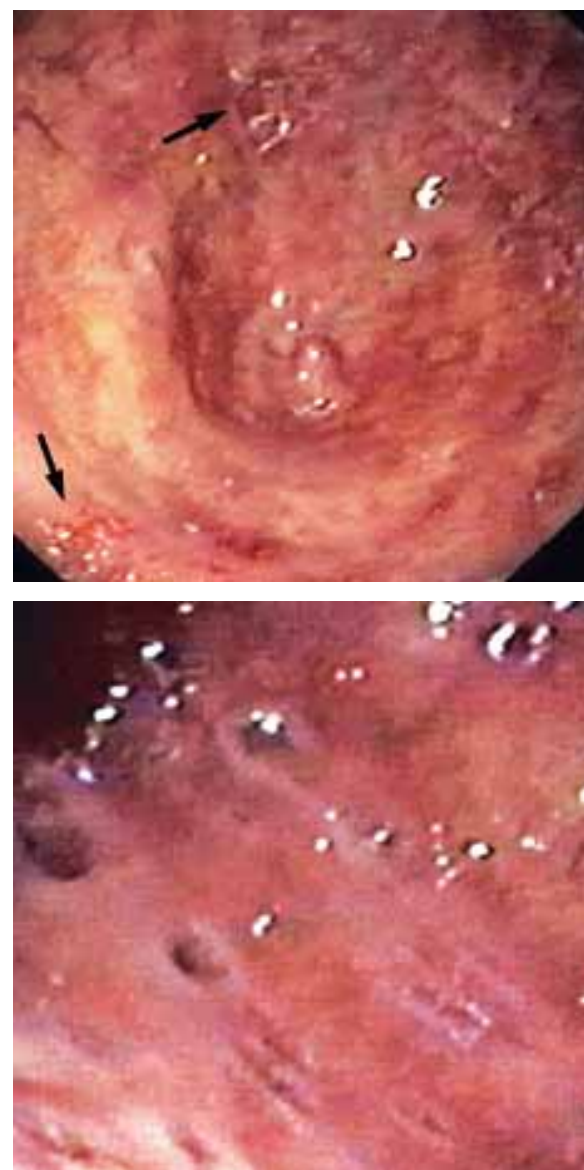

Fig. 1a, b: Hysteroscopic image of an ulcerative endometritis in a mare which was without findings in the clinical, ultrasonographical and microbiological examination of the genital tract (Fig. 1a: the center shows the orifice of the fallopian tube, arrows point at endometrial ulcers)

Hysteroskopisches Bild einer ulzerativen Endometritis bei einer in der klinischen, ultrasonographischen und mikrobiologischen Untersuchung des Genitaltraktes unauffällig gebliebenen Stute (Abb. 1a: mittig stellt sich die papillenförmige Einmündung des Eileiters dar, die Pfeile deuten auf endometriale Ulzera) 
Stage of cycle

In order to establish and maintain uterine distension the choice of the correct stage in the cycle is of considerable importance. It is advantageous to perform a hysteroscopy during diestrus when the cervical seal is tight, because efflux of distension media is minimal at this time and an efficient insufflation is possible (Bracher et al. 1992, LeBlanc 1993, Bartmann et al. 1997, 2000a, Schiemann et al. 2001). Furthermore due to the lack of estrous endometrial oedema the visual assessment of pathological findings is improved (Bartmann et al. 2000a).

Previous experience has shown that the passage of the endoscope through the more or less tightly closed cervix during diestrus is unproblematic.

Anestrus is also a stage in the cycle suitable for establishing adequate visualization and good working conditions (Bartmann et al. 2000a, Schiemann 2001).

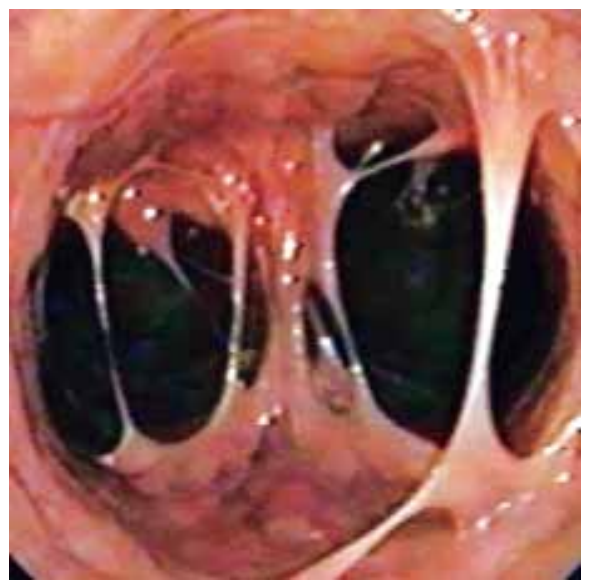

Fig. 2: Intrauterine adhesions in an infertile mare. The previous gynaecological examination was without any pathological findings

Intrauterine Verklebungen einer infertilen Stute. Bei der vorangegangenen gynäkologischen Grunduntersuchung konnten keine die Fertilitätsprobleme erklärenden Befunde erhoben werden.

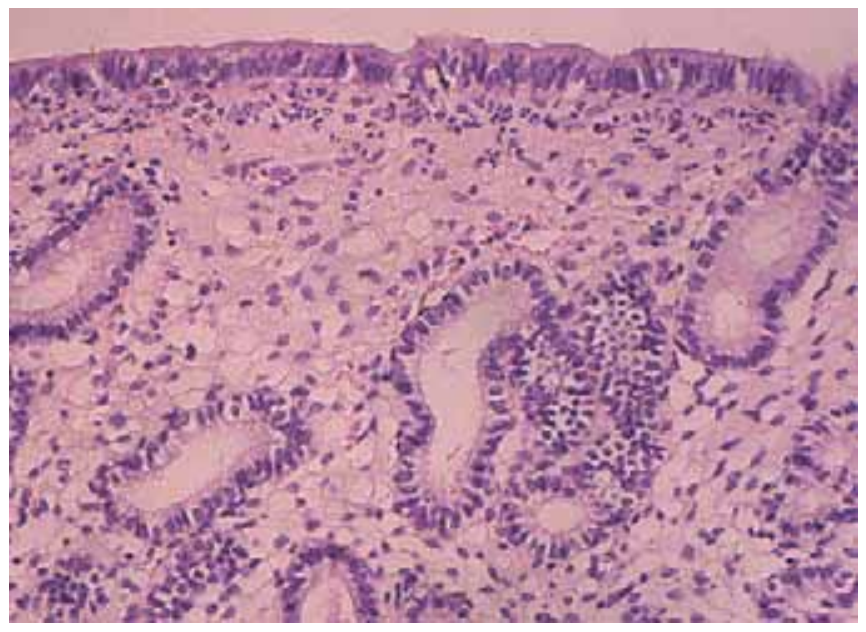

Fig. 3: Light micrographs of the endometrium showing a slight acute superficial purulent endometritis ( $H \& E, x 62,5)$. This endometrial change was found in $75 \%$ of the mares after hysteroscopy

Geringgradige akute oberflächliche eitrige Endometritis in einer lichtmikroskopischen Aufnahme (H\&E, x 62,5). Diese endometriale Reaktion wurde bei $75 \%$ der Stuten nach diagnostischer Hysteroskopie gefunden
Follow-up treatment

In particular when considering the immunological suppressive effect of progesterone, many authors recommend a protective treatment subsequent to hysteroscopy to prevent contamination and the following infection. Some instil antibiotic (LeBlanc 1993), others antiseptic (Bartmann et al. 1997) solutions into the uterus and others induce luteolysis by application of prostaglandins thereby making use of the estrous clearance mechanisms (Bracher et al. 1994).

This study was performed in order to examine the effects of diagnostic hysteroscopy on uterine contamination, endometrial reaction and clinical soundness of the genital tract.

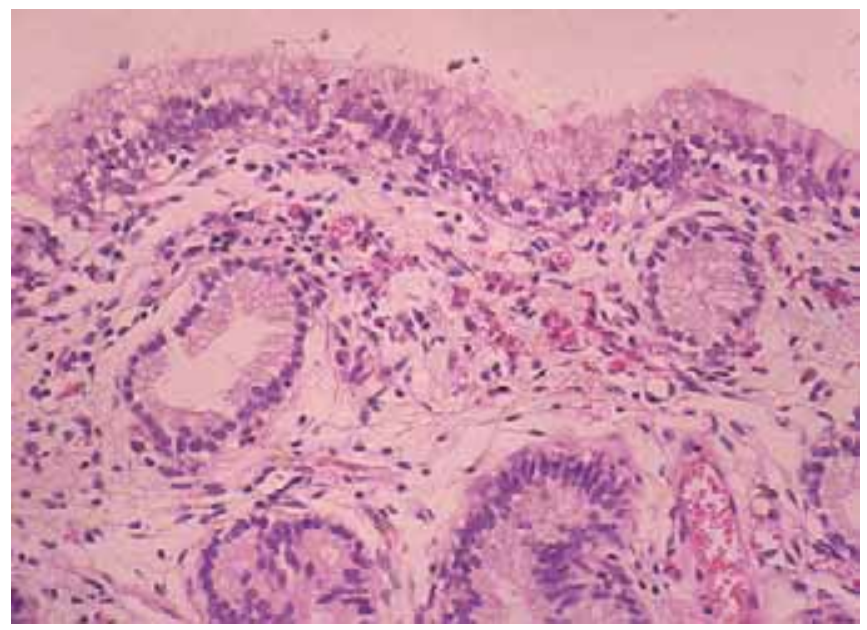

Fig. 4: Endometrial eosinophilia after diagnostic hysteroscopy $(\mathrm{H} \& \mathrm{E}$, $\times$ 62,5)

Endometriale Eosinophilie nach diagnostischer Hysteroskopie (H\&E, x 62,5)

\section{Materials and methods}

Eight diestrous mares (5 Warmblooded, 3 Trotters; age: 12,5 $\pm 4,3$ years; body weight: $520 \pm 50 \mathrm{~kg}$ ) underwent a single diagnostic hysteroscopy.

The mares were restrained in stocks and tranquillized with an iv injection of $0,4 \mathrm{mg} / \mathrm{kg}$ xylazine (Xylapan ${ }^{\circledR}$, Chassot, Ravensburg, Germany) and 0,075 mg/kg levomethadon (Polamivet $^{\circledR}$, Intervet, Munich, Germany). The tail was bandaged and the perineal area was antiseptically prepared by repeated washings using medicated washing solution (Lifosan soft ${ }^{\circledR}, \mathrm{B}$. Braun, Melsungen, Germany) followed by external application of iodine (Braunol ${ }^{\circledR}$, B. Braun, Melsungen, Germany). The endoscope, (SIF 100, Olympus, Hamburg, Germany) desinfected by a mechanical desinfection system (Pauldrach, Garbsen, Germany), was additionally sprayed immediately before insertion with alcoholic solution (Softasept ${ }^{\circledR}$, B. Braun, Melsungen, Germany) and rinsed with sterile saline. One operator, wearing a sterile gown and sterile gloves, inserted the endoscope into the vagina, under manual control, and then into the uterus using digital support. Distension was achieved through insufflation of filtered atmospheric air using the endoscopic pump (cold light source: CLV-U20, Olympus, Hamburg, Germany). A complete exploration of the uterine cavity was performed and finally the uterus was evacuated by 
means of a suction pump (Pauldrach, Garbsen, Germany) connected to the working channel of the endoscope. No followup treatment was carried out.

Immediately before carrying out the hysteroscopy, five days later and after the estrus which followed the mares were examined gynaecologically, and a uterine swab and endometrial biopsy were taken.

The microbiological examination of the uterine swabs for general microbe content was performed by the Institute of Microbiology of the Veterinary Medicine School Hannover. The endometrial biopsies were pathohistologically examined as described by Schoon et al. (1992) and categorized according to the scheme established by Kenney and Doig (1986).

\section{Results}

\section{Before hysteroscopy}

All eight mares were clinically healthy. No pathogenic microbes were evident in the uterine swabs (Table 1). Pathological findings in the endometrial biopsies were solely degenerative alterations (Table 1).

Tab. 1: Findings in uterine swabs (microbiological examination) and endometrial biopsies (histopathological examination) of eight mares taken before performing hysteroscopy

Ergebnisse der mikrobiologischen (Uterustupfer) und pathohistologischen (Endometriumbiopsie) Untersuchung von acht Stuten vor der Hysteroskopie

\begin{tabular}{|c|c|c|c|c|}
\hline Mare & $\begin{array}{c}\text { Micro- } \\
\text { biological } \\
\text { examination }\end{array}$ & Status $^{a}$ & $\begin{array}{l}\text { Histopathologic } \\
\text { examination }\end{array}$ & Category $^{b}$ \\
\hline 1 & $\begin{array}{l}\text { no bacterial } \\
\text { growth }\end{array}$ & $A$ & $\begin{array}{l}+ \text { endometrosis } \\
+ \text { angiosclerosis }\end{array}$ & Ila \\
\hline 2 & $\begin{array}{l}\text { no bacterial } \\
\text { growth }\end{array}$ & $A$ & + endometrosis & Ila \\
\hline 3 & $\begin{array}{l}\text { no bacterial } \\
\text { growth }\end{array}$ & A & $\begin{array}{l}+ \text { endometrosis } \\
++ \text { angiosclerosis }\end{array}$ & Ila \\
\hline 4 & $\begin{array}{l}\text { no bacterial } \\
\text { growth }\end{array}$ & A & $\begin{array}{l}\text { no pathological } \\
\text { findings }\end{array}$ & I \\
\hline 5 & $\begin{array}{l}\text { no bacterial } \\
\text { growth }\end{array}$ & A & $\begin{array}{l}+ \text { endometrosis } \\
+ \text { angiosclerosis }\end{array}$ & Ila \\
\hline 6 & $\begin{array}{l}\text { no bacterial } \\
\text { growth }\end{array}$ & $A$ & $\begin{array}{l}++ \text { endometrosis } \\
+++ \text { angiosclerosis }\end{array}$ & $1 \mathrm{lb}$ \\
\hline 7 & $\begin{array}{l}\text { no bacterial } \\
\text { growth }\end{array}$ & A & $\begin{array}{l}+ \text { endometrosis } \\
++ \text { angiosclerosis }\end{array}$ & Ila \\
\hline 8 & $\begin{array}{l}\text { no bacterial } \\
\text { growth }\end{array}$ & $A$ & $\begin{array}{l}++ \text { endometrosis } \\
+++ \text { angiosclerosis }\end{array}$ & $1 \mathrm{lb}$ \\
\hline
\end{tabular}

aicrobiological status: $\mathrm{A}=$ harmless content of microbes, $\mathrm{B}=$ critical content of microbes

${ }^{\mathrm{b}}$ Categorization based on the system established by Kenney and Doig (1986)

+ mild,++ moderate, +++ severe degree of endometrial change
Microbiological examination

Five days after hysteroscopy one of the mares (no. 3) showed clinical signs of genital inflammation, such as mucous discharge and hyperaemia of the vaginal and cervical mucous membranes. Fluid accumulation in the uterine lumen could be detected by ultrasound. A moderate quantity of Escherichia coli and a slight quantity of beta haemolytic streptococci were found in the uterine swab (Table. 2).

Mares no. 1, 4 and 5 were contaminated with Pseudomonas aeruginosa. Therefore, five days after hysteroscopy, pathogenic microbes were evident in four of eight mares (50\%). In the uterine swabs of the remaining mares only apathogenic (no. 6 and 7) or no (no. 2 and 8) microbes were found.

After the following estrus all mares were clinically healthy. In two mares (no. 1 and no. 5) Pseudomonas aeruginosa persisted, the others were not contaminated with pathogenic microbes (Table 2).

Tab. 2: Results of the microbiological examination of uterine swabs five days after hysteroscopy and after the subsequent estrus

Ergebnisse der mikrobiologischen Untersuchung von Uterustupfern fünf Tage nach Hysteroskopie und nach dem folgenden Östrus

\begin{tabular}{|c|l|c|l|c|}
\hline Mare & \multicolumn{1}{|c|}{ Day 5 } & $\begin{array}{l}\text { Sta- } \\
\text { tus }^{\text {a }}\end{array}$ & After following estrus & $\begin{array}{l}\text { Sta- } \\
\text { tus }^{\mathrm{a}}\end{array}$ \\
\hline 1 & $\begin{array}{l}++ \text { Pseudomonas } \\
\text { aeruginosa }\end{array}$ & B & $\begin{array}{l}\text { + Pseudomonas } \\
\text { aeruginosa }\end{array}$ & B \\
\hline 2 & $\begin{array}{l}\text { no bacterial } \\
\text { growth }\end{array}$ & A & $\begin{array}{l}+ \text { coagulase-negative } \\
\text { staphylococci }\end{array}$ & A \\
\hline 3 & $\begin{array}{l}++ \text { Escherichia } \\
\text { coli beta-haemolytic } \\
\text { streptococci }\end{array}$ & B & $\begin{array}{l}+ \text { alpha-haemolytic } \\
\text { streptococci }\end{array}$ & A \\
\hline 4 & $\begin{array}{l}++ \text { Pseudomonas } \\
\text { aeruginosa }\end{array}$ & B & no bacterial growth & A \\
\hline 5 & $\begin{array}{l}+ \text { Pseudomonas } \\
\text { aeruginosa }\end{array}$ & B & $\begin{array}{l}+++ \text { Pseudomonas } \\
\text { aeruginosa }\end{array}$ & B \\
\hline 6 & $\begin{array}{l}+ \text { Pseudomonas } \\
\text { species }\end{array}$ & A & no bacterial growth \\
\hline 7 & $\begin{array}{l}\text { no bacterial } \\
\text { growth }\end{array}$ & A & A no bacterial growth \\
\hline $\begin{array}{l}+ \text { coagulase-negative } \\
\text { staphylococci } \\
+ \text { alpha-haemolytic } \\
\text { streptococci }\end{array}$ & A \\
\hline
\end{tabular}

a Microbiological status: $A=$ harmless content of microbes, $B=$ critical content of microbes.

+ mild, ++ moderate, +++ high content of microbes

\section{Pathohistological examination}

The clinically manifest endometritis in mare no. 3, five days after hysteroscopy, correlated with the pathohistological diagnosis of a moderate, acute, purulent, superficial endometritis. A further five mares showed a slight, acute, purulent, inflammatory endometrial reaction independent of microbiological contamination (Figure 3 ). Therefore in $75 \%$ of the mares 
inflammatory reactions of the endometrium were found five days after diagnostic hysteroscopy (Table 3).

After the estrus which followed inflammatory alterations were still present in two mares (no. 2 and no. 7) which showed no clinical signs, but could be seen on pathohistological examination of endometrial samples. Mare no. 2 had a slight, acute, purulent endometritis, mare no. 7 a slight, chronic, deep endometritis. In mare no. 3, which transiently suffered from clinical endometritis, neither clinical nor pathohistologically signs of an inflammatory reaction were found after the subsequent estrus (Tab. 3).

\section{Endometrial eosinophilia after diagnostic hysteroscopy}

Independent of the pathohistological diagnosis, mentioned above, most of the mares showed a striking rise in the number of eosinocytes in the Lamina propria mucosa, five days after hysteroscopy (Figure 4). After the following estrus the presence of eosinocytes showed a downward tendency (Table 4).

A lack of an eosinophilic reaction of the endometrium was only noticable in two mares (no. 4 and no. 8). One of them (no. 8) already had an increased number of eosinocytes prior to hysteroscopy (Table 4).

\section{Discussion}

This study shows that in spite of thorough preparation of the mares and strict compliance to antiseptic principles $50 \%$ of the mares were contaminated with pathogenic microbes as a consequence of diagnostic hysteroscopy. One of the mares even developed a clinically manifest endometritis. These facts are inconsistent with the statement made by Leidl and Schallenberger-Pottiez (1976) which states that the contamination caused by hysteroscopy corresponds to that caused when taking a uterine

Tab. 4: Number of eosinocytes in 10 high power fields of the endometrial Lamina propria mucosae before hysteroscopy, five days after and following the subsequent estrus

Anzahl eosinophiler Granulozyten in 10 Blickfeldern (Vergrößerung 1:40) in der Lamina propria mucosae in der Verlaufsuntersuchung

\begin{tabular}{|c|c|c|c|c|c|c|}
\hline \multirow{2}{*}{ Mare } & \multicolumn{2}{|c|}{$\begin{array}{c}\text { Before } \\
\text { hysteroscopy }\end{array}$} & \multicolumn{2}{|c|}{ Day 5} & \multicolumn{2}{|c|}{$\begin{array}{c}\text { After following } \\
\text { estrus }\end{array}$} \\
\hline & $\begin{array}{l}\text { Str. } \\
\text { comp. }\end{array}$ & $\begin{array}{l}\text { Str. } \\
\text { spong. }\end{array}$ & $\begin{array}{l}\text { Str. } \\
\text { comp. }\end{array}$ & $\begin{array}{l}\text { Str. } \\
\text { spong. }\end{array}$ & $\begin{array}{l}\text { Str. } \\
\text { comp. }\end{array}$ & $\begin{array}{c}\text { Str. } \\
\text { spong. }\end{array}$ \\
\hline 1 & 1 & 3 & 18 & 8 & 2 & 2 \\
\hline 2 & 1 & 4 & 25 & 47 & 5 & 6 \\
\hline 3 & 2 & 0 & 55 & 19 & 18 & 2 \\
\hline 4 & 0 & 1 & 2 & 1 & 1 & 1 \\
\hline 5 & 10 & 5 & 51 & 29 & 41 & 26 \\
\hline 6 & 7 & 1 & 61 & 48 & 27 & 15 \\
\hline 7 & 1 & 2 & 31 & 10 & 15 & 5 \\
\hline 8 & 12 & 8 & 7 & 12 & 8 & 8 \\
\hline
\end{tabular}

Str. comp.: Stratum compactum of the endometrial Lamina propria mucosae Str. spong.: Stratum spongiosum of the endometrial Lamina propria mucosae

Tab. 3: Results of the histopathological examination of endometrial biopsies five days after hysteroscopy and after the subsequent estrus Ergebnisse der pathohistologischen Untersuchung von Endometrium-biopsien fünf Tage nach Hysteroskopie und nach dem folgenden Östrus

\begin{tabular}{|c|c|c|c|c|}
\hline Mare & Day 5 & Category ${ }^{b}$ & After subsequent estrus & Category ${ }^{b}$ \\
\hline 1 & $\begin{array}{l}+ \text { endometrosis } \\
+ \text { angiosclerosis }\end{array}$ & Ila & $\begin{array}{l}+ \text { endometrosis } \\
+ \text { angiosclerosis }\end{array}$ & $\| \mathrm{a}$ \\
\hline 2 & $\begin{array}{l}\text { + acute purulent superficial endometritis } \\
+ \text { endometrosis }\end{array}$ & $11 \mathrm{~b}$ & $\begin{array}{l}+ \text { acute purulent superficial endometritis } \\
+ \text { endometrosis }\end{array}$ & Ilb \\
\hline 3 & $\begin{array}{l}++ \text { acute purulent superficial endometritis } \\
+ \text { endometrosis } \\
++ \text { angiosclerosis }\end{array}$ & III & $\begin{array}{l}+ \text { endometrosis } \\
++ \text { angiosclerosis }\end{array}$ & $\| \mathrm{a}$ \\
\hline 4 & $\begin{array}{l}\text { + acute purulent superficial endometritis } \\
+ \text { perivasculitis }\end{array}$ & Ila & no pathologic findings & I \\
\hline 5 & $\begin{array}{l}+ \text { acute purulent superficial endometritis } \\
+ \text { endometrosis } \\
+ \text { angiosclerosis }\end{array}$ & Ilb/III & $\begin{array}{l}+ \text { endometrosis } \\
+ \text { angiosclerosis }\end{array}$ & Ila \\
\hline 6 & $\begin{array}{l}++ \text { endometrosis } \\
+++ \text { angiosclerosis }\end{array}$ & Ilb & $\begin{array}{l}++ \text { endometrosis } \\
+++ \text { angiosclerosis }\end{array}$ & $\mathrm{Ilb}$ \\
\hline 7 & $\begin{array}{l}+ \text { acute purulent superficial endometritis } \\
+ \text { endometrosis } \\
++ \text { angiosclerosis }\end{array}$ & $1 \mathrm{lb}$ & $\begin{array}{l}+ \text { chronical profound endometritis } \\
+ \text { endometrosis } \\
++ \text { angiosclerosis }\end{array}$ & Ilb \\
\hline 8 & $\begin{array}{l}+ \text { acute profound endometritis } \\
++ \text { endometrosis } \\
+++ \text { angiosclerosis }\end{array}$ & III & $\begin{array}{l}++ \text { endometrosis } \\
+++ \text { angiosclerosis }\end{array}$ & Ilb \\
\hline
\end{tabular}

${ }^{b}$ Categorization based on the system established by Kenney and Doig (1986). + mild, ++ moderate, +++ severe degree of endometrial 
swab.

The high incidence of contamination with Pseudomonas aeruginosa was striking. In three of four mares this microbe was found in the uterine swab. Bracher et al. (1994) mention that following laser surgical adhesiolysis two of four mares were infected with Pseudomonas and showed an endometritis despite the induction of estrus. Contamination caused by the endoscope unit could be excluded as is the case in this study. Concurring with Bracher et al. (1994) it seems likely that this microbe was introduced from the peripheral genital tract during hysteroscopy. After the following estrus none of the mares showed clinical signs of pathological alterations of the genital tract, despite the fact that no follow-up treatment had been administered. In two mares (no. 1 and no. 5) Pseudomonas persisted without causing an endometrial reaction. In spite of good self-clearance in these mares, it is recommended that patients which are considered to be adversely affected undergo a metaphylactic treatment subsequent to hysteroscopy. LeBlanc (1993) administers antibiotic solutions locally, Bartmann et al. (1997) instil $100 \mathrm{ml}$ of a mild antiseptic solution, which is $1 \%$ povidoniodine $\left(\right.$ Braunol $^{\circledR}, \mathrm{B}$. Braun, Melsungen, Germany ) in saline. Uterine clearance would be more effective in combination with the induction of estrus, as suggested by Bracher et al. (1994), however application of prostaglandins, as the only measure, might be insufficient.

In $75 \%$ of the mares acute, purulent, primarily superficial inflammatory reactions were pathohistologically evident, and persisted, in two mares, after the subsequent estrus (no. 2 and no. 7). Because this inflammatory alteration, based on the infiltration of neutrophilic granulocytes, was not always accompanied by contamination, it is possible that this reaction is at least partially founded on non-bacterial causes such as chemical or mechanical irritations. Although this slight inflammatory endometrial reaction only takes place at a histological level, Bartmann et al. (1997) recommend excluding the following estrus for insemination, even after non-surgical hysteroscopy. Induction of estrus as applied by Bracher et al. (1994) might accelerate this process.

A very interesting finding of the pathohistological examination was the strikingly large infiltration of the endometrial Lamina propria mucosae by eosinocytes, five days after hysteroscopy, in almost all of the mares. After the following estrus a downward trend was noticeable, however the number of eosinocytes still remained above the initial value. There was neither a relationship to the quality and quantity of microbes found in the uterine swab nor was there a correlation with the purulent, endometrial inflammatory reaction present. Therefore the observation of Slusher et al. (1984) that eosinocytes are exclusively found in combination with a neutrophilia is disproved by this study.

Hurtgen and Cummings (1982) make an infection with yeasts responsible for endometritis eosinophilica in horses. This aetiology can be excluded in this case. In comparison Slusher et al. (1984) make a connection between poor vulvovestibular conformation, with the resulting pneumouterus, and an increased number of eosinocytes in the endometrial biopsy. Based on their own examination material Schoon et al. (1997) are unable to comprehend any of these theories.

The results of this study show that in almost all mares an obvious endometrial eosinophilia was induced by the distension of the uterus with filtered atmospheric air. This reaction might be caused by the exposure of the endometrium to air as suggested by Slusher et al. (1984), as well as by the mechanical irritation of the tissue caused by elevated intrauterine pressure. Further examinations are necessary in order to ascertain the precise aetiology.

\section{Conclusion}

As a follow-up treatment for mares that undergo hysteroscopy, local application of antiseptic solutions, such as 1\% povidoniodine, into the uterus is recommended. Instillation of antibiotic solutions does not correspond to the guidelines for the application of antibiotics (Bundestierärztekammer 2000). Because of frequently induced inflammatory endometrial reaction caused by hysteroscopy the subsequent estrus should not be used for breeding. Acceleration of the process and therefore an earlier opportunity for insemination can be achieved through the induction of estrus using prostaglandins. During progesterone dominated diestrus immunosuppression makes the uterus more susceptible to infections (Squires 1993), which can be avoided by using the correct follow-up treatment. Use should be made of the advantages of diestrus, which include feasible maintainance of distension and better visibility due to the absence of endometrial oedema.

\section{Literature}

Bartmann, C.P., I. Brickwedel and E. Klug (2000a): Hysteroskopische hochfrequenzchirurgische Behandlung intrauteriner Adhäsionen beim Pferd. Tierärztl. Prax. 28, 233-239

Bartmann, C.P., V. Schiemann, I. Brickwedel and E. Klug (2000b): Minimal invasive Chirurgie zur hysteroskopischen Behandlung von Uteruszysten und anderer intrauteriner Sterilitätsursachen beim Pferd. Proc. IV. Intern. Congr. small anim. horses in Vienna, 199-207

Bartmann, C.P., A. Schöning, I. Brickwedel, B. Ohnesorge and E. Klug (1997): Hysteroskopie und minimal invasive endouterine Chirurgie bei der Stute. Pferdeheilkd. 13, 474-482

Bracher, V., S. Mathias and W.R. Allen (1992): Videoendoscopic evaluation of the mare's uterus: II. Findings in subfertile mares. Equine Vet. J. 24, 279-284

Bracher, V., R. Stone and W.R. Allen (1994): Transendoscopic Nd:YAG laser surgery for treatment of intrauterine adhesions in 4 mares. Equine Vet. Educ. 6, 22-26

Bundestierärztekammer (2000): Leitlinien für den sorgfältigen Umgang mit antimikrobiell wirksamen Tierarzneimitteln. Dt. Tierärzteblatt 48 (11), Beilage

Hurtgen, J.P., and M.R. Cummings (1982): Diagnosis and treatment of fungal endometritis in mares. Proc. Ann. Meet. Soc. Theriogenology, 18-22

Kähn, W. (1993): Endoskopie im Rahmen der Reproduktion bei Stuten. In: W. Kraft (Ed.): Tierärztliche Endoskopie. 1. Edition, Schattaver, Stuttgart, New York, 142-150

Kenney, R.M. and P.A. Doig (1986): Equine endometrial biopsy. In: D.A. Morrow (Ed.): Current therapy in theriogenology. 2. Edition, Saunders, Philadelphia, 723-729

LeBlanc, M.M. (1993): Endoscopy. In: McKinnon, A.O. and J.L. Voss (Ed.): Equine Reproduction. 1. Edition, Lea \& Febiger, Philadelphia, London, 255-257

Leidl, W. and U. Schallenberger-Pottiez (1976): Zur Hysteroskopie bei 
der Stute. Veterinärmed. Nachr. 2, 203-217

Morris, L.H., R.H. Hunter and W.R. Allen (2000): Hysteroscopic insemination of small numbers of spermatozoa at the uterotubal junction of preovulatory mares. J. Reprod. Fertil. 118 (1), 95-100

Schiemann, V. (2001): Untersuchungen zur Uterusdistension und intrauterine Druckentwicklung bei der Hysteroskopie des Pferdes. Hannover, Tierärztl. Hochsch., Diss.

Schiemann, V., C.P. Bartmann, A. Baudler and E. Klug (2000): Untersuchung intrauteriner Druckverhältnisse zur Optimierung der Hysteroskopie beim Pferd. In: Tagungsbericht der Arbeitstagung Fachgruppe Pferdekrankh. der DVG, Tutzing, 06./07.09.2000, 7886

Schiemann, V., C.P. Bartmann and H.-O. Hoppen (2001): Einfluss des Serumprogesterons auf die Uterusdistension anlässlich der Hysteroskopie beim Pferd. Pferdeheilk. 17, 161-164

Schoon, H.-A., D. Schoon and E. Klug (1992): Uterusbiopsien als Hilfsmittel für Diagnose und Prognose von Fertilitätsstörungen der Stute. Pferdeheilk. 8, 355-362

Schoon, H.-A., D. Schoon and E. Klug (1997): Die Endometriumsbiopsie bei der Stute im klinisch-gynäkologischen Kontext. Pferdeheilk. 13, 453-464

Slusher, S.H., K.P. Freeman and J.F. Roszel (1984): Eosinophils in equine uterine cytology and histology specimens. J. Am. Vet. Med. Assoc.
$184,665-670$

Squries, E.L. (1993): Progesterone. In: McKinnon, A.O. and J.L. Voss (Ed.): Equine Reproduction. 1. Edition, Lea \& Febiger, Philadelphia, London, 57-64

Threllfall, R.W., and C.L. Carlton (1997): Mare's genital tract. In: J.L. Traub-Dargatz and C.M. Brown (Ed.): Equine Endoscopy. 2. Edition, Mosby, St. Louis, 204-217

Wilson, G.L. (1983): Equine hysteroscopy: a window to the internal reproductive tract. Vet. med. Small Anim. Clin. 78, 1455-1466

\section{Acknowledgement}

The authors would like to thank Stefan Witte for checking through the english translation of this text.

\section{Dr. Viola Schiemann}

\section{Klinik für Pferde}

Tierärztliche Hochschule Hannover

Bischofsholer Damm 15

30173 Hannover

Tel.: (0511) 8567233

fax: (0517) 8567688 